
September 1938

\title{
PHASE EQUILIBRIA STUDIES ON MIXTURES OF THE COMPOUNDS $4 \mathrm{CaO} \cdot \mathrm{Al}_{2} \mathrm{O}_{3} \cdot \mathrm{Fe}_{2} \mathrm{O}_{3}-2 \mathrm{CaO} \cdot \mathrm{Fe}_{2} \mathrm{O}_{3}-\mathrm{K}_{2} \mathrm{O} \cdot \mathrm{Al}_{2} \mathrm{O}_{3}$
}

\author{
By William C. Taylor ${ }^{1}$
}

\begin{abstract}
A portion of the system $\mathrm{CaO}-\mathrm{Al}_{2} \mathrm{O}_{3}-\mathrm{Fe}_{2} \mathrm{O}_{3}-\mathrm{K}_{2} \mathrm{O}$ has been investigated. The quenching method of study of phase equilibria was employed. No ternary compounds containing $\mathrm{K}_{2} \mathrm{O}$ were observed. The compounds $\mathrm{K}_{2} \mathrm{O} . \mathrm{Al}_{2} \mathrm{O}_{3}$ and $4 \mathrm{CaO} . \mathrm{Al}_{2} \mathrm{O}_{3} \cdot \mathrm{Fe}_{2} \mathrm{O}_{3}$ were found to form a binary system with one eutectic. Since it was observed that, for a given ratio of $4 \mathrm{CaO} \cdot \mathrm{Al}_{2} \mathrm{O}_{3} \cdot \mathrm{Fe}_{2} \mathrm{O}_{3}$ to $2 \mathrm{CaO} \cdot \mathrm{Fe}_{2} \mathrm{O}_{3}$, the solid solution of these two compounds and $\mathrm{K}_{2} \mathrm{O} \cdot \mathrm{Al}_{2} \mathrm{O}_{3}$ resembled a binary system with a single eutectic, these compounds are considered as forming a pseudobinary system. Pertinent optical and thermal data have been presented. Temperatureconcentration diagrams for sections of the quaternary system are constructed.
\end{abstract}

\section{CONTENTS}

I. Introduction

II. Experimental method

III. Phase equilibria

1. The system $4 \mathrm{CaO} \cdot \mathrm{Al}_{2} \mathrm{O}_{3} \cdot \mathrm{Fe}_{2} \mathrm{O}_{3}-\mathrm{K}_{2} \mathrm{O} \cdot \mathrm{Al}_{2} \mathrm{O}_{3} \ldots \ldots$

2. Relations of $4 \mathrm{CaO} \cdot \mathrm{Al}_{2} \mathrm{O}_{3} \cdot \mathrm{Fe}_{2} \mathrm{O}_{3}-2 \mathrm{CaO} \cdot \mathrm{Fe}_{2} \mathrm{O}_{3}$

3. Relations of 90 percent of $4 \mathrm{CaO} \cdot \mathrm{Al}_{2} \mathrm{O}_{3} \cdot \mathrm{Fe}_{2} \mathrm{O}_{3}, 10$ percent of $2 \mathrm{CaO} . \mathrm{Fe}_{2} \mathrm{O}_{3}-\mathrm{K}_{2} \mathrm{O} \cdot \mathrm{Al}_{2} \mathrm{O}_{3}$

4. Relations of 70 percent of $4 \mathrm{CaO} \cdot \mathrm{Al}_{2} \mathrm{O}_{3} \cdot \mathrm{Fe}_{2} \mathrm{O}_{3}, 30$ percent of $2 \mathrm{CaO} . \mathrm{Fe}_{2} \mathrm{O}_{3}-\mathrm{K}_{2} \mathrm{O} . \mathrm{Al}_{2} \mathrm{O}_{3}$

5. Relations of 50 percent of $4 \mathrm{CaO} \cdot \mathrm{Al}_{2} \mathrm{O}_{3} \cdot \mathrm{Fe}_{2} \mathrm{O}_{3}, 50$ percent of $2 \mathrm{CaO} . \mathrm{Fe}_{2} \mathrm{O}_{3}-\mathrm{K}_{2} \mathrm{O} \cdot \mathrm{Al}_{2} \mathrm{O}_{3} \ldots \ldots \ldots$

6. General relations of $4 \mathrm{CaO} \cdot \mathrm{Al}_{2} \mathrm{O}_{3} \cdot \mathrm{Fe}_{2} \mathrm{O}_{3}-2 \mathrm{CaO} \cdot \mathrm{Fe}_{2} \mathrm{O}_{3}-\mathrm{K}_{2} \mathrm{O} \cdot \mathrm{Al}_{2} \mathrm{O}_{3}--322$

IV. Significance of the study in regard to the constitution of portland cement 323

V. Summary _...

VI. References...

\section{INTRODUCTION}

Fundamental thermal studies on various systems of the components of portland cement have, for several years, occupied a prominent part in the program of the Portland Cement Association Fellowship at the National Bureau of Standards. Likewise, other workers have made important contributions in this field. Brownmiller and Bogue $[1]^{2}$ present a comprehensive bibliography in this connection with their paper "The X-ray Method Applied to A Study of the Constitution of Portland Cement." These studies referred to, together with subsequent data obtained by Lea and Parker [2], Dahl [3], and

\footnotetext{
${ }^{1}$ Research Associate at the National Bureau of Standards, representing the Portland Cement Association Fellowship.

${ }^{2}$ Figures in brackets indicate the literature references at the end of this paper.
} 
McMurdie and Insley [4], among others, form the basis of the present conception of the constitution of portland cement with reference to the principal oxides, namely, $\mathrm{CaO}, \mathrm{SiO}_{2}, \mathrm{Al}_{2} \mathrm{O}_{3}, \mathrm{Fe}_{2} \mathrm{O}_{3}$, and $\mathrm{MgO}$.

Of the minor constituents, the alkalies, because of their prevalence, are probably the most important. It was found by the analyses of 23 commercial clinkers used in connection with a current study by the fellowship staff that $\mathrm{Na}_{2} \mathrm{O}$ and $\mathrm{K}_{2} \mathrm{O}$ each was present in all clinkers. The amount of the former varied from 0.1 to 0.7 percent, and the amount of the latter from 0.1 to 1.6 percent. The average percentage of each was 0.3 and 0.6 , respectively. While these percentages in themselves are of small magnitude, combination of the alkalies with the other constituents may be such as to have a significant effect on the ratio of lime to the remaining acidic constituents available.

Accordingly, studies of systems involving the alkalies are being made as a continuation of the series undertaken for the purpose of establishing the constitution of portland cement clinker. The system $\mathrm{CaO}-\mathrm{Na}_{2} \mathrm{O}-\mathrm{Al}_{2} \mathrm{O}_{3}$ has been examined by Brownmiller and Bogue [5] and the system $\mathrm{CaO}-\mathrm{K}_{2} \mathrm{O}-\mathrm{Al}_{2} \mathrm{O}_{3}$ by Brownmiller [6].

It was found that $\mathrm{K}_{2} \mathrm{O} \cdot \mathrm{Al}_{2} \mathrm{O}_{3}$ is the only compound of $\mathrm{K}_{2} \mathrm{O}$ which is stable at the liquidus in the portion of the $\mathrm{CaO}-\mathrm{K}_{2} \mathrm{O}-\mathrm{Al}_{2} \mathrm{O}_{3}$ system studied. This means that $\mathrm{K}_{2} \mathrm{O} \cdot \mathrm{Al}_{2} \mathrm{O}_{3}$ will crystallize from the melt in all portions of the diagram which were studied. But this does not necessarily mean that $\mathrm{K}_{2} \mathrm{O} \cdot \mathrm{Al}_{2} \mathrm{O}_{3}$ exists in portland cement clinker. Before the manner in which $\mathrm{K}_{2} \mathrm{O}$ is combined in clinker can be predicted, thermal studies of systems involving $\mathrm{K}_{2} \mathrm{O} \cdot \mathrm{Al}_{2} \mathrm{O}_{3}$ and the silica and the iron compounds of cement are necessary. The present investigation on a portion of the system $\mathrm{CaO}-\mathrm{Al}_{2} \mathrm{O}_{3}-\mathrm{Fe}_{2} \mathrm{O}_{3}-\mathrm{K}_{2} \mathrm{O}$ is one of such studies.

\section{EXPERIMENTAL METHOD}

Four series of base compositions were made. In each series the ratio of $4 \mathrm{CaO} \cdot \mathrm{Al}_{2} \mathrm{O}_{3} \cdot \mathrm{Fe}_{2} \mathrm{O}_{3}$ to $2 \mathrm{CaO} \cdot \mathrm{Fe}_{2} \mathrm{O}_{3}$ (by weight) was constant but the $\mathrm{K}_{2} \mathrm{O} \cdot \mathrm{Al}_{2} \mathrm{O}_{3}$ content varied. The ratios of $4 \mathrm{CaO} \cdot \mathrm{Al}_{2} \mathrm{O}_{3} \cdot \mathrm{Fe}_{2} \mathrm{O}_{3}$ to $2 \mathrm{CaO} . \mathrm{Fe}_{2} \mathrm{O}_{3}$ employed were 100:0, 90:10, 70:30, and 50:50. The percentage of $\mathrm{K}_{2} \mathrm{O} \cdot \mathrm{Al}_{2} \mathrm{O}_{3}$ in the 100:0 series varied from 0 to 60 , but in the other series from 0 to 25 .

In preparing the base compositions, $4 \mathrm{CaO} \cdot \mathrm{Al}_{2} \mathrm{O}_{3} \cdot \mathrm{Fe}_{2} \mathrm{O}_{3}$ and $2 \mathrm{CaO}$.$\mathrm{Fe}_{2} \mathrm{O}_{3}$ were first made independently. These compounds were mixed in the desired proportions and then the $\mathrm{Al}_{2} \mathrm{O}_{3}$ and $\mathrm{K}_{2} \mathrm{O}$ were added separately. Potassium oxalate was used as the source of $\mathrm{K}_{2} \mathrm{O}$ since it is not hygroscopic and weighing difficulties are eliminated by its use. After the addition of $\mathrm{Al}_{2} \mathrm{O}_{3}$ and $\mathrm{K}_{2} \mathrm{O}$, the samples were burned at about $1,250^{\circ} \mathrm{C}$ for $1 / 2$ hour. The amount of $\mathrm{K}_{2} \mathrm{O}$ in the sample was checked by determining the weight difference before and after burning. Corrections were made when necessary. Potash does not appear to be volatilized rapidly after it has once combined and for that reason combination was first effected by the preliminary burning at temperatures not exceeding $1,250^{\circ} \mathrm{C}$.

The small quenching charges were taken from the base samples which had been thoroughly ground after each step in the preparation. These charges were tightly enclosed in platinum foil, the edges of the foil being folded over at least three times. Heating was for as short a time as possible (15 to 20 minutes was found to be ample to bring about equilibrium) in order to avoid loss of potash. The consistency 
with which various melting temperatures could be checked was accepted as evidence that the loss of $\mathrm{K}_{2} \mathrm{O}$ resulting from this procedure was slight.

Very small samples were used because the utmost rapidity is required in quenching. Even so, in samples containing the high percentages of the iron compounds, quench growths were found to occur and interpretations had to be made accordingly. In most studies of systems containing $\mathrm{Fe}_{2} \mathrm{O}_{3}$, heretofore, the quenching method has been limited in use because of the rapid crystallization of the iron compounds. Thermal studies were made with heating curves. However, in the presence of alkalies, thermocouples are readily attacked and for this reason the quenching method is necessary.

The charges were suspended by a very fine platinum wire in the hot zone of a vertical platinum-rhodium resistance furnace. Temperatures were measured by means of a platinum, platinum-rhodium thermocouple connected with a Leeds and Northup potentiometer. Temperature control was effected by the use of a Robert's regulator [7]. Because of the susceptibility to attack by the potash, the thermocouple in use was calibrated frequently by comparison with a standard couple held in reserve, or by checking the melting points of eutectics in the $\mathrm{CaO}-\mathrm{Al}_{2} \mathrm{O}_{3}$ system.

The common procedure of thermal study by the quenching method was followed, whereby the appearance of the sample under the petrographic microscope is used as a means for determining the condition of the charge at the temperature of the furnace just prior to the quenching.

The samples containing $\mathrm{K}_{2} \mathrm{O}$ were found to be very hygroscopic and extreme precautions were necessary to avoid hydration of the quenches. The agate mortar and pestle with which they were ground had to be heated previously, and the portions to be examined transferred directly and quickly to the microscope slide.

\section{PHASE EQUILIBRIA}

\section{THE SYSTEM $4 \mathrm{CaO} \cdot \mathrm{Al}_{2} \mathrm{O}_{3} \cdot \mathrm{Fe}_{2} \mathrm{O}_{3}-\mathrm{K}_{2} \mathrm{O} \cdot \mathrm{Al}_{2} \mathrm{O}_{3}$}

Only compositions within the range from 100 percent of $4 \mathrm{CaO} \cdot \mathrm{Al}_{2} \mathrm{O}_{3} \cdot \mathrm{Fe}_{2} \mathrm{O}_{3}$ to 60 percent of $4 \mathrm{CaO} \cdot \mathrm{Al}_{2} \mathrm{O}_{3} \cdot \mathrm{Fe}_{2} \mathrm{O}_{3}-40$ percent of $\mathrm{K}_{2} \mathrm{O} \cdot \mathrm{Al}_{2} \mathrm{O}_{3}$ were investigated. In regions high in $\mathrm{K}_{2} \mathrm{O} \cdot \mathrm{Al}_{2} \mathrm{O}_{3}$, complete melting of the charges occurs only at very high temperatures. At such temperatures a certain amount of uncertainty is felt as to the accuracy of the data obtained because of the likelihood of loss of $\mathrm{K}_{2} \mathrm{O}$ by volatilization. Although varying amounts of $\mathrm{K}_{2} \mathrm{O}$ are lost upon prolonged heat treatment, no dissociation of $\mathrm{K}_{2} \mathrm{O} . \mathrm{Al}_{2} \mathrm{O}_{3}$ was observed in the sense that there exists some definite dissociation temperature. Moreover, all of the information which may be pertinent to portlandcement composition can be obtained from that part of the system in which the percentages of $\mathrm{K}_{2} \mathrm{O}$ are low, because cements are low in $\mathrm{K}_{2} \mathrm{O}$ generally.

No evidence of any compounds other than $4 \mathrm{CaO} \cdot \mathrm{Al}_{2} \mathrm{O}_{3} \cdot \mathrm{Fe}_{2} \mathrm{O}_{3}$ and $\mathrm{K}_{2} \mathrm{O} \cdot \mathrm{Al}_{2} \mathrm{O}_{3}$ was obtained. The results indicate that the system is a binary system with one eutectic having the composition 81 percent of $4 \mathrm{CaO} \cdot \mathrm{Al}_{2} \mathrm{O}_{3} \cdot \mathrm{Fe}_{2} \mathrm{O}_{3}-19$ percent of $\mathrm{K}_{2} \mathrm{O} \cdot \mathrm{Al}_{2} \mathrm{O}_{3}$. The eutectic melts at $1,343^{\circ} \pm 5^{\circ} \mathrm{C}$. On the $\mathrm{K}_{2} \mathrm{O} \cdot \mathrm{Al}_{2} \mathrm{O}_{3}$ side of this composition, the melting points rise very rapidly; the melting point of the composition 
containing 25 percent of $\mathrm{K}_{2} \mathrm{O} \cdot \mathrm{Al}_{2} \mathrm{O}_{3}$ being $1,520^{\circ} \pm 5^{\circ} \mathrm{C}$. The melting relations in this binary system are shown in table 1 . In addition to the data given in the table, the eutectic melting temperature and composition were checked by observing the temperature at which liquid disappeared when compositions on each side of the eutectic composition were cooled from higher temperatures. A partial temperature-concentration diagram of this system is given in figure 1(A).

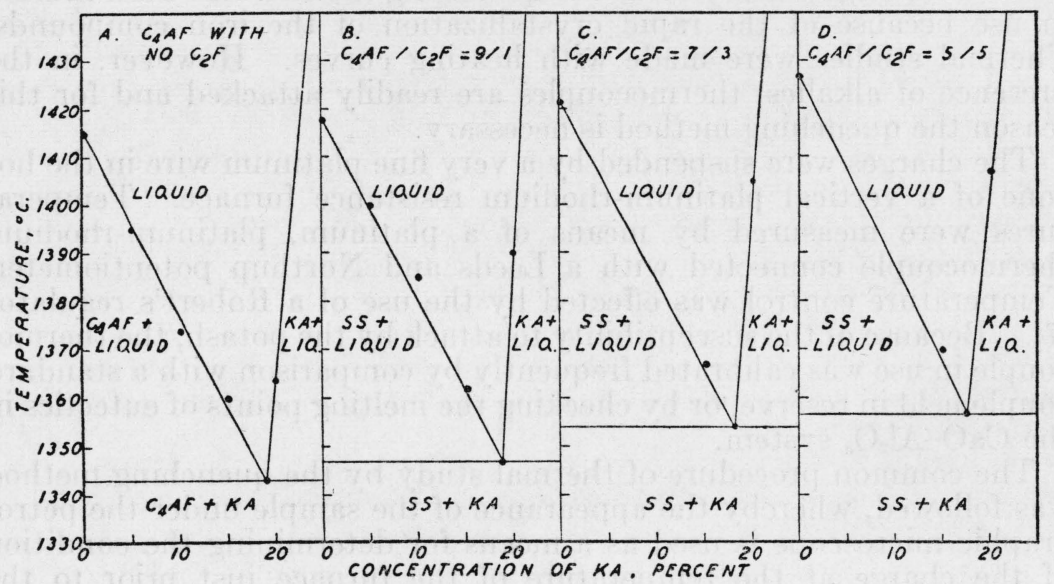

FIGURE 1.-Temperature-concentration diagram showing the melting relations of $\mathrm{C}_{4} \mathrm{AF}$ with $\mathrm{KA}$ and of solid solutions of $\mathrm{C}_{4} \mathrm{AF}+\mathrm{C}_{2} \mathrm{~F}$ (designated $S S$ ) with KA.

TABLE 1.-Thermal data relative to the system $\mathrm{C}_{4} \mathrm{AF}-\mathrm{KA}$

\begin{tabular}{|c|c|c|c|}
\hline \multicolumn{2}{|c|}{ Composition } & \multirow{2}{*}{$\begin{array}{c}\text { Temperature } \\
\text { of } \\
\text { quench }\end{array}$} & \multirow{2}{*}{ Examination } \\
\hline $\mathrm{C}_{4} \mathrm{AF}$ & $\mathbf{K A}$ & & \\
\hline $\begin{array}{l}\text { Percent } \\
100\end{array}$ & $\begin{array}{l}\text { Percent } \\
0\end{array}$ & 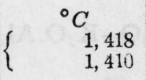 & $\begin{array}{l}\text { Glass; few quench growths. } \\
\text { All crystalline. }\end{array}$ \\
\hline 95 & 5 & $\begin{array}{l}1,400 \\
1,391 \\
1,340\end{array}$ & $\begin{array}{l}\text { Glass. } \\
\text { Very small amount } \mathrm{C}_{4} \mathrm{AF} \text {; glass. } \\
\text { All crystalline. }\end{array}$ \\
\hline 90 & 10 & $\begin{array}{l}1,378 \\
1,370 \\
1,348 \\
1,340\end{array}$ & $\begin{array}{l}\text { Glass. } \\
\mathrm{C}_{4} \mathrm{AF} \text {; glass. } \\
\text { Do. } \\
\mathrm{C}_{4} \mathrm{AF} ; \mathrm{KA} .\end{array}$ \\
\hline 85 & 15 & $\begin{array}{l}1,364 \\
1,356 \\
1,348\end{array}$ & $\begin{array}{l}\text { Glass; very few quench growths. } \\
\text { CAAF; glass. } \\
\text { Do. }\end{array}$ \\
\hline 80 & 20 & $\begin{array}{l}1,365 \\
1,360 \\
1,343\end{array}$ & $\begin{array}{l}\text { Glass. } \\
\text { KA; glass. } \\
\text { Very small amount of glass; KA; } \mathrm{C}_{\mathbf{1}} \mathrm{AF} \text {. }\end{array}$ \\
\hline 75 & 8 & $\begin{array}{l}1,520 \\
1,500\end{array}$ & $\begin{array}{l}\text { Glass; only trace of KA. } \\
\mathrm{KA} \text {; glass. }\end{array}$ \\
\hline 70 & 30 & $\begin{array}{l}1,560 \\
1,345 \\
1,340\end{array}$ & $\begin{array}{l}\text { Do. } \\
\text { KA; glass; quench growths. } \\
\mathrm{KA} \mathrm{C}_{4} \mathrm{AF} \text {. }\end{array}$ \\
\hline $\begin{array}{l}60 \\
40\end{array}$ & $\begin{array}{l}40 \\
60\end{array}$ & $\begin{array}{l}1,340 \\
1,580\end{array}$ & $\begin{array}{l}\mathrm{KA} ; \mathrm{C}_{4} \mathrm{AF} ; \text { trace of glass. } \\
\mathrm{KA} ; \text { glass. }\end{array}$ \\
\hline
\end{tabular}


The compound $4 \mathrm{CaO} \cdot \mathrm{Al}_{2} \mathrm{O}_{3} \cdot \mathrm{Fe}_{2} \mathrm{O}_{3}$ apparently takes up some $\mathrm{K}_{2} \mathrm{O}$. $\mathrm{Al}_{2} \mathrm{O}_{3}$ in solid solution, inasmuch as there exists a difference in pleochroism of the $4 \mathrm{CaO} \cdot \mathrm{Al}_{2} \mathrm{O}_{3} \cdot \mathrm{Fe}_{2} \mathrm{O}_{3}$ grains in the absence and presence of $\mathrm{K}_{2} \mathrm{O} \cdot \mathrm{Al}_{2} \mathrm{O}_{3}$. The amount of solid solution must be very limited, however, because only a slight change in the indices of refraction of the $4 \mathrm{CaO} \cdot \mathrm{Al}_{2} \mathrm{O}_{3} \cdot \mathrm{Fe}_{2} \mathrm{O}_{3}$ was observed. The compound $\mathrm{K}_{2} \mathrm{O} \cdot \mathrm{Al}_{2} \mathrm{O}_{3}$, likewise, takes up some $4 \mathrm{CaO} \cdot \mathrm{Al}_{2} \mathrm{O}_{3} \cdot \mathrm{Fe}_{2} \mathrm{O}_{3}$ in solid solution. The grains of $\mathrm{K}_{2} \mathrm{O} \cdot \mathrm{Al}_{2} \mathrm{O}_{3}$ containing $4 \mathrm{CaO} \cdot \mathrm{Al}_{2} \mathrm{O}_{3} \cdot \mathrm{Fe}_{2} \mathrm{O}_{3}$ show no birefraction, but the index of refraction has a value of 1.625 as compared with the index of 1.603 , the value ascribed to the pure compound by Brownmiller [6]. It is doubtful that the amount of $4 \mathrm{CaO} \cdot \mathrm{Al}_{2} \mathrm{O}_{3} \cdot \mathrm{Fe}_{2} \mathrm{O}_{3}$ which goes into solution in the $\mathrm{K}_{2} \mathrm{O} \cdot \mathrm{Al}_{2} \mathrm{O}_{3}$ is appreciable, because the $\mathrm{K}_{2} \mathrm{O} \cdot \mathrm{Al}_{2} \mathrm{O}_{3}$ grains do not lose their isotropism. $\mathrm{K}_{2} \mathrm{O} \cdot \mathrm{Al}_{2} \mathrm{O}_{3}$ was found to crystallize as colorless, rounded grains, which sometimes had the appearance of octahedrons. Possible further evidence of solid solution of $4 \mathrm{CaO}$. $\mathrm{Al}_{2} \mathrm{O}_{3} \cdot \mathrm{Fe}_{2} \mathrm{O}_{3}$ was found in the optical properties of the $\mathrm{K}_{2} \mathrm{O} \cdot \mathrm{Al}_{2} \mathrm{O}_{3}$ crystals contained in a charge of the composition 70 percent of $4 \mathrm{CaO}$. $\mathrm{Al}_{2} \mathrm{O}_{3} \cdot \mathrm{Fe}_{2} \mathrm{O}_{3}-30$ percent of $\mathrm{K}_{2} \mathrm{O} \cdot \mathrm{Al}_{2} \mathrm{O}_{3}$, which had been cooled slowly from $1,372^{\circ}$ to $1,320^{\circ} \mathrm{C}$. The index of the grains, in general, was about 1.625 , but in some of the grains there were portions which appeared to have an index of about 1.61 or a trifle lower. No grains which had a index intermediate to the values 1.625 and 1.61 were observed. This would indicate that the slightest amount of solid solution is sufficient to raise the index to the maximum value of 1.625 . Because the amounts of solid solution are indeterminate, the solid solutions are not indicated in figure 1(A), and the solidus is represented by a straight line.

\section{RELATIONS OF $4 \mathrm{CaO} \cdot \mathrm{Al}_{2} \mathrm{O}_{3} \cdot \mathrm{Fe}_{2} \mathrm{O}_{3}-2 \mathrm{CaO} \cdot \mathrm{Fe}_{2} \mathrm{O}_{3}$}

Hansen, Brownmiller, and Bogue [8] found that $4 \mathrm{CaO} \cdot \mathrm{Al}_{2} \mathrm{O}_{3} \cdot \mathrm{Fe}_{2} \mathrm{O}_{3}$ and $2 \mathrm{CaO} . \mathrm{Fe}_{2} \mathrm{O}_{3}$ form a complete series of solid solutions. The temperature-concentration diagram as constructed by them is reproduced in figure 2. Ordinarily the figure demonstrating a complete

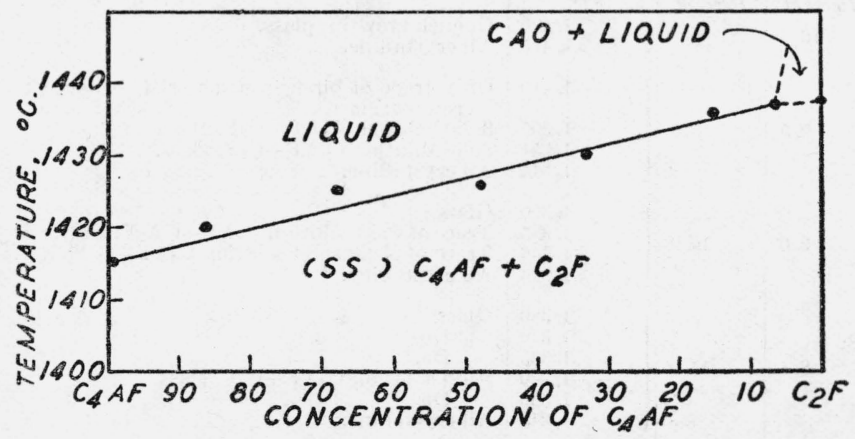

FIGURE 2.-Temperature-concentration diagram showing the melting relations in the solid solution of $\mathrm{C}_{4} \mathrm{AF}$ and $\mathrm{C}_{2} \mathrm{~F}$.

series of solid solutions consists of two curves, representing the liquidus and the solidus, respectively. In this particular case, these workers found that the melting range of the solid solutions could not be determined. The heating curve method of study was employed and 
only one distinct break was obtained on each of the heating curves. The conclusion drawn was that the melting range of these solid solutions is very narrow, and, consequently the temperature-concentration diagram was constructed with a single curve.

\section{RELATIONS OF 90 PERCENT OF $4 \mathrm{CaO} \cdot \mathrm{Al}_{2} \mathrm{O}_{3} \cdot \mathrm{Fe}_{2} \mathrm{O}_{3}, 10$ PERCENT OF $2 \mathrm{CaO} . \mathrm{Fe}_{2} \mathrm{O}_{3}-\mathrm{K}_{2} \mathrm{O} . \mathrm{Al}_{2} \mathrm{O}_{3}$}

The series of compositions having the amounts of $4 \mathrm{CaO} \cdot \mathrm{Al}_{2} \mathrm{O}_{3} \cdot \mathrm{Fe}_{2} \mathrm{O}_{3}$ and $2 \mathrm{CaO} . \mathrm{Fe}_{2} \mathrm{O}_{3}$ in the definite ratio of $9: 1$, respectively, and in which the percentage of $\mathrm{K}_{2} \mathrm{O} \cdot \mathrm{Al}_{2} \mathrm{O}_{3}$ varies, cannot be considered as a true binary system, although $4 \mathrm{CaO} \cdot \mathrm{Al}_{2} \mathrm{O}_{3} \cdot \mathrm{Fe}_{2} \mathrm{O}_{3}$ and $2 \mathrm{CaO} \cdot \mathrm{Fe}_{2} \mathrm{O}_{3}$ do go into solid solution and separate as one phase. Strictly speaking, as the solid solution melts, there exists a difference in the compositions of the liquid and the remaining solid. But, as has been mentioned above, the melting range is very narrow and the difference in composition between the liquid and solid phases necessarily must be slight. Since, except for the most exacting interpretations, the relationships which obtain are similar to those of a binary system this may be referred to as forming a pseudobinary system. (For the same reason, compositions in which $4 \mathrm{CaO} \cdot \mathrm{Al}_{2} \mathrm{O}_{3} \cdot \mathrm{Fe}_{2} \mathrm{O}_{3}$ and $2 \mathrm{CaO} \cdot \mathrm{Fe}_{2} \mathrm{O}_{3}$ are in some other definite ratio are treated as belonging to a pseudobinary system in conjunction with $\mathrm{K}_{2} \mathrm{O} \cdot \mathrm{Al}_{2} \mathrm{O}_{3}$.)

The composition represented by the lowest point on the liquidus curve is 81.5 percent of $4 \mathrm{CaO} \cdot \mathrm{Al}_{2} \mathrm{O}_{3} \cdot \mathrm{Fe}_{2} \mathrm{O}_{3}+2 \mathrm{CaO} \cdot \mathrm{Fe}_{2} \mathrm{O}_{3}$ (73.35 percent of $4 \mathrm{CaO} \cdot \mathrm{Al}_{2} \mathrm{O}_{3} \cdot \mathrm{Fe}_{2} \mathrm{O}_{3}, 8.15$ percent of $2 \mathrm{CaO} . \mathrm{Fe}_{2} \mathrm{O}_{3}$ ) and 18.5 percent of $\mathrm{K}_{2} \mathrm{O} \cdot \mathrm{Al}_{2} \mathrm{O}_{3}$. The melting point of this mixture is $1,347^{\circ}$ $\pm 5^{\circ} \mathrm{C}$.

TABLE 2.-Thermal data relative to mixtures of $\mathrm{C}_{4} \mathrm{AF}+\mathrm{C}_{2} \mathrm{~F}$ (9 to 1)-KA

\begin{tabular}{|c|c|c|c|c|}
\hline \multicolumn{3}{|c|}{ Composition } & \multirow{2}{*}{$\begin{array}{c}\text { Temperature } \\
\text { of quench }\end{array}$} & \multirow{2}{*}{ Examination } \\
\hline $\mathrm{C}_{4} \mathrm{AF}$ & $\mathrm{C}_{2} \mathrm{~F}$ & $\mathrm{KA}$ & & \\
\hline Percent & Percent & Percent & ${ }^{\circ} \mathrm{C}$ & \\
\hline 90 & 10 & 0 & $\left\{\begin{array}{r}1,420 \\
1,415\end{array}\right.$ & $\begin{array}{l}\text { Quench growths; glass. } \\
\text { All crystalline. }\end{array}$ \\
\hline & & & 1,410 & $\begin{array}{l}\text { Only trace of biref. iron material, believed to be quench } \\
\text { growths; glass. }\end{array}$ \\
\hline 85.5 & 9.5 & 5.0 & $\begin{array}{l}1,395 \\
1,351 \\
1,345\end{array}$ & $\begin{array}{l}\text { Solid solution } \mathrm{C}_{4} \mathrm{AF}+\mathrm{C}_{2} \mathrm{~F} \text {; glass. } \\
\text { Solid solution } \mathrm{C}_{4} \mathrm{AF}+\mathrm{C}_{2} \mathrm{~F} \text {; glass. } \\
\text { All crystalline. }\end{array}$ \\
\hline 81.0 & 9.0 & 10.0 & $\begin{array}{l}1,390 \\
1,385 \\
1346 \\
1,343\end{array}$ & $\begin{array}{l}\text { Glass. } \\
\text { Trace of solid solution } \mathrm{C}_{4} \mathrm{AF}+\mathrm{CA}_{2} \mathrm{~F} \text {; glass. } \\
\text { Trace of glass; solid solution } \mathrm{C}_{4} \mathrm{AF}+\mathrm{C}_{2} \mathrm{~F} ; \mathrm{KA} \text {. } \\
\text { All crystalline. }\end{array}$ \\
\hline 76.5 & 8.5 & 15. 0 & $\begin{array}{l}1,380 \\
1,370 \\
1,365 \\
1,360 \\
1,355 \\
1,343\end{array}$ & $\begin{array}{l}\text { Glass. } \\
\text { Do. } \\
\text { Do. } \\
\text { Solid solution } \mathrm{C}_{4} \mathrm{AF}+\mathrm{C}_{2} \mathrm{~F} \text {; glass. } \\
\text { Do. } \\
\text { All crystalline. }\end{array}$ \\
\hline 72.0 & 8.0 & 20.0 & $\begin{array}{l}1,390 \\
1,380 \\
1,370 \\
1,360 \\
1,350\end{array}$ & $\begin{array}{l}\text { Trace of KA; glass. } \\
\text { KA; glass. } \\
\text { Do. } \\
\text { Do. } \\
\text { Do. }\end{array}$ \\
\hline 67.5 & 7.5 & 25.0 & $\begin{array}{l}1,530 \\
1,520 \\
1,354 \\
1,346\end{array}$ & $\begin{array}{l}\text { Glass. } \\
\text { KA; glass. } \\
\text { Do. } \\
\text { Trace of glass; } \mathrm{KA} \text {; solid solution } \mathrm{C}_{4} \mathrm{AF}+\mathrm{C}_{2} \mathrm{~F} \text {. }\end{array}$ \\
\hline
\end{tabular}


The melting relations are given in table 2 and the temperatureconcentration diagram is shown in figure $1(\mathrm{~B})$. It will be observed that the same type of temperature-concentration relationships obtain as those which hold for the $4 \mathrm{CaO} \cdot \mathrm{Al}_{2} \mathrm{O}_{3} \cdot \mathrm{Fe}_{2} \mathrm{O}_{3}-\mathrm{K}_{2} \mathrm{O} \cdot \mathrm{Al}_{2} \mathrm{O}_{3}$ system without the $2 \mathrm{CaO} \cdot \mathrm{Fe}_{2} \mathrm{O}_{3}$.

The index of $\mathrm{K}_{2} \mathrm{O} . \mathrm{Al}_{2} \mathrm{O}_{3}$ was found to be 1.625 . The birefracting iron-bearing phase had the indices; $\alpha_{\mathrm{L} 1} 1.98$ and $\gamma_{\mathrm{L} 1}$ about 2.05 . These indices agree closely with those determined by Hansen, Brownmiller, and Bogue [8] for this particular solid solution.

\section{RELATIONS OF 70 PERCENT OF $4 \mathrm{CaO} . \mathrm{Al}_{2} \mathrm{O}_{3} \cdot \mathrm{Fe}_{2} \mathrm{O}_{3}, 30$ PERCENT OF $2 \mathrm{CaO} . \mathrm{Fe}_{2} \mathrm{O}_{3}-\mathrm{K}_{2} \mathrm{O} . \mathrm{Al}_{2} \mathrm{O}_{3}$}

The melting points of compositions in this series are slightly higher than those of comparable compositions of the preceding series. The composition 82 percent of $4 \mathrm{CaO} \cdot \mathrm{Al}_{2} \mathrm{O}_{3} \cdot \mathrm{Fe}_{2} \mathrm{O}_{3}+2 \mathrm{CaO} \cdot \mathrm{Fe}_{2} \mathrm{O}_{3}$ (57.4 percent of $4 \mathrm{CaO} \cdot \mathrm{Al}_{2} \mathrm{O}_{3} \cdot \mathrm{Fe}_{2} \mathrm{O}_{3}, 24.6$ percent of $2 \mathrm{CaO} . \mathrm{Fe}_{2} \mathrm{O}_{3}$ ) and 18 percent of $\mathrm{K}_{2} \mathrm{O} \cdot \mathrm{Al}_{2} \mathrm{O}_{3}$, which melts at $1,354^{\circ} \pm 5^{\circ} \mathrm{C}$, is the lowest-melting composition. No additional compounds were observed. $\mathrm{K}_{2} \mathrm{O} \cdot \mathrm{Al}_{2} \mathrm{O}_{3}$ grains retain their index of 1.625 . The minimum index for lithium light of the crystalline solid solution of $4 \mathrm{CaO} \cdot \mathrm{Al}_{2} \mathrm{O}_{3} \cdot \mathrm{Fe}_{2} \mathrm{O}_{3}$ and $2 \mathrm{CaO} \cdot \mathrm{Fe}_{2} \mathrm{O}_{3}$ was found to be about 2.05 . This value is very close to that which was read from the diagram constructed by Hansen, Brownmiller, and Bogue [8] in which the indices of refraction of the solid solutions are plotted against composition. The thermal relations of compositions in this pseudobinary system are given in table 3 and the graphic interpretation is shown in figure $1(\mathbf{C})$.

TABLE 3.-Thermal data relative to mixtures of $\mathrm{C}_{4} \mathrm{AF}+\mathrm{C}_{2} \mathrm{~F}(7$ to 3$)-\mathrm{KA}$

\begin{tabular}{|c|c|c|c|c|}
\hline \multicolumn{3}{|c|}{ Composition } & \multirow{2}{*}{$\begin{array}{l}\text { Temperature } \\
\text { of quench }\end{array}$} & \multirow{2}{*}{ Examination } \\
\hline $\mathrm{C}_{4} \mathrm{AF}$ & $\mathrm{C}_{2} \mathrm{~F}$ & $\mathrm{KA}$ & & \\
\hline Percent & Percent & Percent & ${ }^{\circ} \mathrm{C}$ & \\
\hline 70.0 & 30.0 & 0.0 & $\begin{array}{l}1,425 \\
1,420\end{array}$ & $\begin{array}{l}\text { Glass; quench growths. } \\
\text { Mostly crystalline; trace of glass. }\end{array}$ \\
\hline 66.5 & 28.5 & 5.0 & $\begin{array}{l}1,430 \\
1,420 \\
1,410 \\
1,362 \\
1,357 \\
1,353 \\
1,340\end{array}$ & $\begin{array}{l}\text { Glass; quench growths. } \\
\text { Do. } \\
\text { Do. } \\
\text { Solid solution } \mathrm{C}_{4} \mathrm{AF}+\mathrm{C}_{2} \mathrm{~F} ; \text { glass. } \\
\text { Solid solution } \mathrm{C}_{4} \mathrm{AF}+\mathrm{C}_{2} \mathrm{~F} ; \text { small amount of glass. } \\
\text { Solid solution } \mathrm{C}_{4} \mathrm{AF}+\mathrm{C}_{2} \mathrm{~F} ; \mathrm{KA} ; \text { only trace of glass. } \\
\text { All crystalline. }\end{array}$ \\
\hline 63.0 & 27.0 & 10.0 & $\begin{array}{l}1,420 \\
1,410 \\
1,357 \\
1,350\end{array}$ & $\begin{array}{l}\text { Glass; quench growths. } \\
\text { Do. } \\
\text { Solid solution } \mathrm{C}_{4} \mathrm{AF}+\mathrm{C}_{2} \mathrm{~F} \text {; glass. } \\
\text { All crystalline. }\end{array}$ \\
\hline 59.5 & 25.5 & 15.0 & $\begin{array}{l}1,380 \\
1,370 \\
1,365 \\
1,357 \\
1,350\end{array}$ & $\begin{array}{l}\text { Glass. } \\
\text { Do. } \\
\text { Solid solution } \mathrm{C}_{4} \mathrm{AF}+\mathrm{C}_{2} \mathrm{~F} ; \text { glass. } \\
\text { Solid solution } \mathrm{C}_{4} \mathrm{AF}+\mathrm{C}_{2} \mathrm{~F} ; \mathrm{KA} ; \text { small amount of glass. } \\
\text { All crystalline. }\end{array}$ \\
\hline 56.0 & 24.0 & 20.0 & $\begin{array}{l}1,410 \\
1,400 \\
1,390\end{array}$ & $\begin{array}{l}\text { Glass. } \\
\text { KA; glass. } \\
\text { Do. }\end{array}$ \\
\hline 52.5 & 22.5 & 25.0 & $\begin{array}{l}1,520 \\
1,510 \\
1,357 \\
1,350\end{array}$ & $\begin{array}{l}\text { Trace of KA; glass. } \\
\text { KA; glass. } \\
\text { Poorly defined crystals; some glass. } \\
\text { All crystalline. }\end{array}$ \\
\hline
\end{tabular}




\section{RELATIONS OF 50 PERCENT OF $4 \mathrm{CaO} . \mathrm{Al}_{2} \mathrm{O}_{3} \cdot \mathrm{Fe}_{2} \mathrm{O}_{3}, 50$ PERCENT OF $2 \mathrm{CaO} . \mathrm{Fe}_{2} \mathrm{O}_{3}-\mathrm{K}_{2} \mathrm{O} . \mathrm{Al}_{2} \mathrm{O}_{3}$}

The same relationships hold for this pseudobinary system as for the preceding systems in which one component is composed of $4 \mathrm{CaO}$. $\mathrm{Al}_{2} \mathrm{O}_{3} \cdot \mathrm{Fe}_{2} \mathrm{O}_{3}$ and $2 \mathrm{CaO} \cdot \mathrm{Fe}_{2} \mathrm{O}_{3}$ in a definite proportion. The melting points are, in general, increased as a result of the increased amount of $2 \mathrm{CaO} . \mathrm{Fe}_{2} \mathrm{O}_{3}$ in the solid solution. The composition of the lowestmelting compostion is 82.5 percent of $4 \mathrm{CaO} \cdot \mathrm{Al}_{2} \mathrm{O}_{3} \cdot \mathrm{Fe}_{2} \mathrm{O}_{3}+2 \mathrm{CaO} \cdot \mathrm{Fe}_{2} \mathrm{O}_{3}$ (41.25 percent of $4 \mathrm{CaO} \cdot \mathrm{Al}_{2} \mathrm{O}_{3} \cdot \mathrm{Fe}_{2} \mathrm{O}_{3}, 41.25$ percent of $2 \mathrm{CaO} . \mathrm{Fe}_{2} \mathrm{O}_{3}$ ) and 17.5 percent of $\mathrm{K}_{2} \mathrm{O} \cdot \mathrm{Al}_{2} \mathrm{O}_{3}$. It melts at $1,357^{\circ} \pm 5^{\circ} \mathrm{C}$. The data pertaining to the quenches in this system are shown in table 4, and the temperature-concentration diagram in figure (D). The index of $\mathrm{K}_{2} \mathrm{O} \cdot \mathrm{Al}_{2} \mathrm{O}_{3}$, as in the preceding systems, was 1.625 . The minimum index for lithium light of the crystalline iron-bearing material was slightly less than 2.10, probably 2.08. This value, likewise, is in close agreement with that reported by Hansen, Brownmiller, and Bogue.

TABLE 4.-Thermal data relative to mixtures of $\mathrm{C}_{4} \mathrm{AF}+\mathrm{C}_{2} \mathrm{~F}$ (5 to 5)-KA

\begin{tabular}{|c|c|c|c|c|}
\hline \multicolumn{3}{|c|}{ Composition } & \multirow{2}{*}{$\begin{array}{l}\text { Temperature } \\
\text { of quench }\end{array}$} & \multirow{2}{*}{ Examination } \\
\hline $\mathrm{C}_{4} \mathrm{AF}$ & $\mathrm{C}_{2} \mathrm{~F}$ & KA & & \\
\hline $\begin{array}{l}\text { Percent } \\
50\end{array}$ & $\begin{array}{l}\text { Percent } \\
50\end{array}$ & $\begin{array}{c}\text { Percent } \\
0\end{array}$ & ${ }^{\circ} \mathrm{C}$ & Melting temperature $1,427^{\circ} \mathrm{O}$, according to Hansen, \\
\hline $\begin{array}{l}47.5 \\
45.0\end{array}$ & $\begin{array}{l}47.5 \\
45.0\end{array}$ & $\begin{array}{r}5.0 \\
10.0\end{array}$ & $\begin{array}{l}1,357 \\
1,357\end{array}$ & $\begin{array}{l}\text { Few quench growths; mostiy crystalline. }{ }^{1} \\
\text { D } 0.1\end{array}$ \\
\hline 42.5 & 42.5 & 15.0 & $\begin{array}{l}1,380 \\
1,370\end{array}$ & $\begin{array}{l}\text { Glass. } \\
\text { Trace solid solution } \mathrm{C}_{4} \mathrm{AF}+\mathrm{C}_{2} \mathrm{~F} \text {; glass. }\end{array}$ \\
\hline 40.0 & 40.0 & 20.0 & $\begin{array}{l}1,410 \\
1,405 \\
1,357\end{array}$ & $\begin{array}{l}\text { Glass. } \\
\mathrm{KA} \text {; glass. } \\
\mathrm{KA} \text {; some solid solution } \mathrm{C}_{4} \mathrm{AF}+\mathrm{C}_{2} \mathrm{~F} \text {; trace of glass. }\end{array}$ \\
\hline 37.5 & 37.5 & 25.0 & $\begin{array}{l}1,530 \\
1,520 \\
1,515\end{array}$ & $\begin{array}{l}\text { Glass. } \\
\text { Trace KA; glass. } \\
\text { Much KA; glass. }\end{array}$ \\
\hline
\end{tabular}

1 Quenches of samples containing less than 15 percent of KA were very unsatisfactory.

\section{GENERAL RELATIONS OF $4 \mathrm{CaO} \cdot \mathrm{Al}_{2} \mathrm{O}_{3} \cdot \mathrm{Fe}_{2} \mathrm{O}_{3} \cdot 2 \mathrm{CaO} \cdot \mathrm{Fe}_{2} \mathrm{O}_{3}-\mathrm{K}_{2} \mathrm{O} \cdot \mathrm{Al}_{2} \mathrm{O}_{3}$}

No compounds of potash other than $\mathrm{K}_{2} \mathrm{O} \cdot \mathrm{Al}_{2} \mathrm{O}_{3}$ were found to exist at equilibrium in the region studied. The compound $4 \mathrm{CaO} \cdot \mathrm{Al}_{2} \mathrm{O}_{3} \cdot \mathrm{Fe}_{2} \mathrm{O}_{3}$ is stable in the presence of $\mathrm{K}_{2} \mathrm{O} \cdot \mathrm{Al}_{2} \mathrm{O}_{3}$ and forms a series of solid solutions with $2 \mathrm{CaO} . \mathrm{Fe}_{2} \mathrm{O}_{3}$ as it does in the absence of $\mathrm{K}_{2} \mathrm{O} \cdot \mathrm{Al}_{2} \mathrm{O}_{3}$. Figure 3 is the diagram showing the fields of primary crystallization and the $1,400^{\circ}$ and $1,500^{\circ} \mathrm{C}$ isotherms. The boundary curve separating the field of $\mathrm{K}_{2} \mathrm{O} \cdot \mathrm{Al}_{2} \mathrm{O}_{3}$ from the field of the solid solutions of $4 \mathrm{CaO} \cdot \mathrm{Al}_{2} \mathrm{O}_{3} \cdot \mathrm{Fe}_{2} \mathrm{O}_{3}$ and $2 \mathrm{CaO} . \mathrm{Fe}_{2} \mathrm{O}_{3}$ may be considered as defining the lowest-melting compositions which will exist in any mixture of $\mathrm{K}_{2} \mathrm{O} \cdot \mathrm{Al}_{2} \mathrm{O}_{3}, 4 \mathrm{CaO} \cdot \mathrm{Al}_{2} \mathrm{O}_{3} \cdot \mathrm{Fe}_{2} \mathrm{O}_{3}$, and $2 \mathrm{CaO} \cdot \mathrm{Fe}_{2} \mathrm{O}_{3}$ in which the ratio of $4 \mathrm{CaO} . \mathrm{Al}_{2} \mathrm{O}_{3} \cdot \mathrm{Fe}_{2} \mathrm{O}_{3}$ to $2 \mathrm{CaO}$. $\mathrm{Fe}_{2} \mathrm{O}_{3}$ does not exceed 1.0 (the limit of the region studied). It will be seen that the percentage of $\mathrm{K}_{2} \mathrm{O} \cdot \mathrm{Al}_{2} \mathrm{O}_{3}$ present in the lowest-melting compositions decreases slightly as the ratio of $4 \mathrm{CaO} \cdot \mathrm{Al}_{2} \mathrm{O}_{3} \cdot \mathrm{Fe}_{2} \mathrm{O}_{3}$ to $2 \mathrm{CaO} \cdot \mathrm{Fe}_{2} \mathrm{O}_{3}$ decreases. There is a small rise in the melting temperatures of these compositions as the ratio of $4 \mathrm{CaO} . \mathrm{Al}_{2} \mathrm{O}_{3} \cdot \mathrm{Fe}_{2} \mathrm{O}_{3}$ to $2 \mathrm{CaO} . \mathrm{Fe}_{2} \mathrm{O}_{3}$ decreases, as shown in 
figure 1. The temperatures required for complete melting of the compositions in the field in which $\mathrm{K}_{2} \mathrm{O} . \mathrm{Al}_{2} \mathrm{O}_{3}$ is the primary phase, increase very sharply as the percentage of $\mathrm{K}_{2} \mathrm{O} \cdot \mathrm{Al}_{2} \mathrm{O}_{3}$ increases.

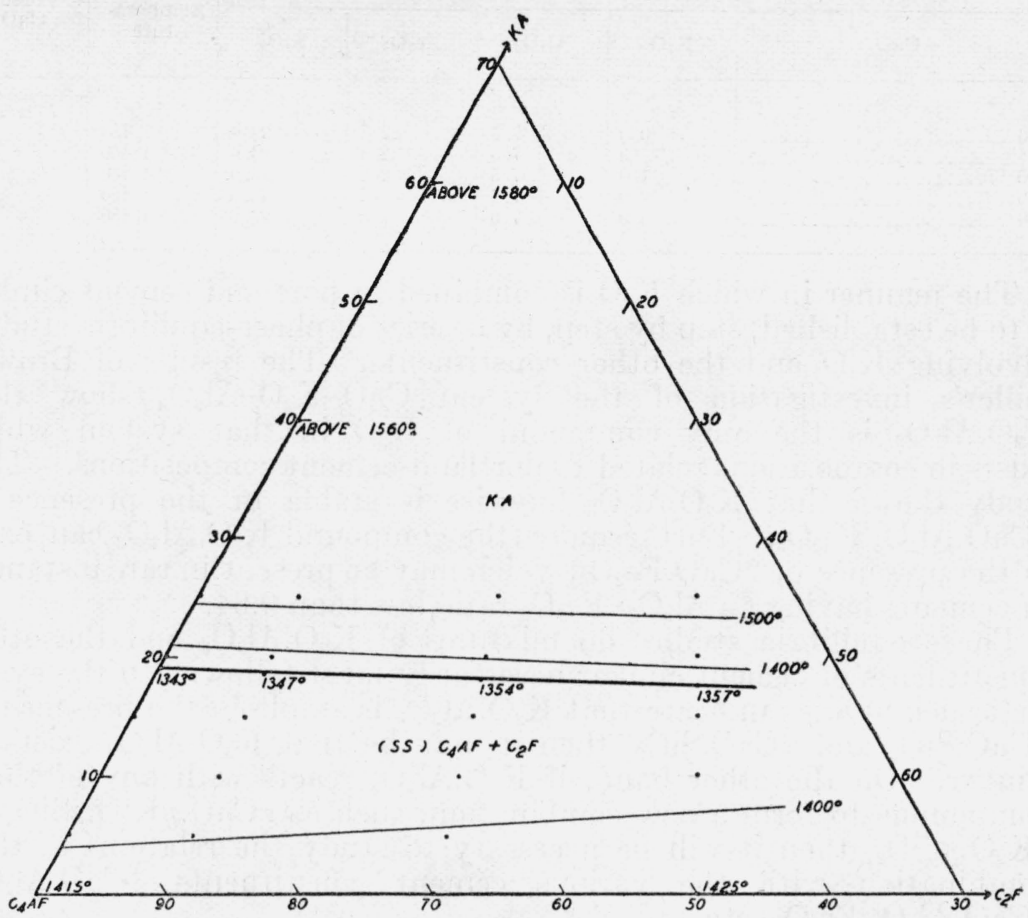

FIGURe 3.-Diagram showing fields of primary crystallization and isotherms with mixtures of $\mathrm{C}_{4} \mathrm{AF}, \mathrm{C}_{2} \mathrm{~F}$, KA.

\section{SIGNIFICANCE OF THE STUDY IN REGARD TO THE CONSTITUTION OF PORTLAND CEMENT}

Although the alkalies generally are referred to as being among the minor constituents of portland cement clinker, it is recognized that $\mathrm{K}_{2} \mathrm{O}$ and $\mathrm{Na}_{2} \mathrm{O}$ may combine with other oxides present in such a manner as to be of great effect in determining the ultimate composition. It was found in a study of the influence of $\mathrm{K}_{2} \mathrm{O}$ on the burnability of cement compositions in this laboratory [9] that, although the first small increments of $\mathrm{K}_{2} \mathrm{O}$ favored combination, higher free-lime values obtained in clinkers burned at a definite temperature as $\mathrm{K}_{2} \mathrm{O}$ was substituted for like percentages of $\mathrm{CaO}$ beyond an optimum value. This optimum amount was found to vary with the composition of the base mixture, but, generally was less than 1 percent. A typical example is given in table 5 . 
TABLE 5.-The effect of varying amounts of $\mathrm{K}_{2} \mathrm{O}$ on the combination of $\mathrm{CaO}$ at a definite temperature

\begin{tabular}{|c|c|c|c|c|c|c|}
\hline \multicolumn{5}{|c|}{ Percentage composition of mixture } & \multirow{2}{*}{$\begin{array}{c}\text { Burning } \\
\text { tempera- } \\
\text { ture }\end{array}$} & \multirow{2}{*}{$\begin{array}{l}\text { Free } \\
\mathrm{CaO}\end{array}$} \\
\hline $\mathrm{CaO}$ & $\mathrm{K}_{2} \mathrm{O}$ & $\mathrm{Al}_{2} \mathrm{O}_{3}$ & $\mathrm{Fe}_{2} \mathrm{O}_{3}$ & $\mathrm{SiO}_{2}$ & & \\
\hline 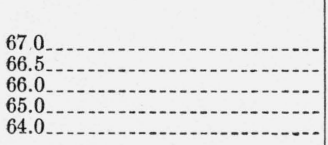 & $\begin{array}{l}0.0 \\
.5 \\
1.0 \\
2.0 \\
3.0\end{array}$ & $\begin{array}{l}7.5 \\
7.5 \\
7.5 \\
7.5 \\
7.5\end{array}$ & $\begin{array}{l}2.5 \\
2.5 \\
2.5 \\
2.5 \\
2.5\end{array}$ & $\begin{array}{l}23.0 \\
23.0 \\
23.0 \\
23.0 \\
23.0\end{array}$ & $\begin{array}{l}{ }^{\circ} C \\
1,450 \\
1,450 \\
1,450 \\
1,450 \\
1,450\end{array}$ & $\begin{array}{r}\text { Percent } \\
1.1 \\
.5 \\
1.6 \\
4.3 \\
7.3\end{array}$ \\
\hline
\end{tabular}

The manner in which $\mathrm{K}_{2} \mathrm{O}$ is combined in portland cement clinker is to be established, step by step, by a series of phase-equilibria studies involving $\mathrm{K}_{2} \mathrm{O}$ and the other constituents. The results of Brownmiller's investigation of the system $\mathrm{CaO}-\mathrm{K}_{2} \mathrm{O}-\mathrm{Al}_{2} \mathrm{O}_{3}$ show that $\mathrm{K}_{2} \mathrm{O} \cdot \mathrm{Al}_{2} \mathrm{O}_{3}$ is the only compound of $\mathrm{K}_{2} \mathrm{O}$ in that system which exists in compositions related to portland-cement compositions. This study shows that $\mathrm{K}_{2} \mathrm{O} . \mathrm{Al}_{2} \mathrm{O}_{3}$ likewise is stable in the presence of $4 \mathrm{CaO} \cdot \mathrm{Al}_{2} \mathrm{O}_{3} \cdot \mathrm{Fe}_{2} \mathrm{O}_{3}$. Furthermore, the compound $\mathrm{K}_{2} \mathrm{O} \cdot \mathrm{Al}_{2} \mathrm{O}_{3}$ can exist in the presence of $2 \mathrm{CaO} \cdot \mathrm{Fe}_{2} \mathrm{O}_{3}$, which may be present in rare instances in cements having an $\mathrm{Al}_{2} \mathrm{O}_{3}: \mathrm{Fe}_{2} \mathrm{O}_{3}$ ratio less than 0.64.

Phase equilibria studies on mixtures of $\mathrm{K}_{2} \mathrm{O} \cdot \mathrm{Al}_{2} \mathrm{O}_{3}$ and the other constituents of cement clinker necessarily must follow. In the event that such studies indicate that $\mathrm{K}_{2} \mathrm{O} \cdot \mathrm{Al}_{2} \mathrm{O}_{3}$ is stable in the presence of $3 \mathrm{CaO} . \mathrm{SiO}_{2}$ and $2 \mathrm{CaO} . \mathrm{SiO}_{2}$, then it may be that $\mathrm{K}_{2} \mathrm{O} \cdot \mathrm{Al}_{2} \mathrm{O}_{3}$ exists in clinker. On the other hand, if $\mathrm{K}_{2} \mathrm{O} \cdot \mathrm{Al}_{2} \mathrm{O}_{3}$ reacts with any of these compounds to form a new combination, such as $x \mathrm{CaO} . y \mathrm{~K}_{2} \mathrm{O} . z \mathrm{SiO}_{2}$ or $x \mathrm{~K}_{2} \mathrm{O} \cdot y \mathrm{SiO}_{2}$, then it will be necessary to study the relations of that combination with the various cement constituents $3 \mathrm{CaO} \cdot \mathrm{Al}_{2} \mathrm{O}_{3}$, $4 \mathrm{CaO} \cdot \mathrm{Al}_{2} \mathrm{O}_{3} \cdot \mathrm{Fe}_{2} \mathrm{O}_{3}$, etc.

In view of recent discoveries by Insley and McMurdie (10), the latter condition appears to be likely. With the development of the technique for examining polished sections of clinkers in reflected light, these workers have observed a dark prismatic interstitial material in many commercial cement clinkers. It was found that this material did not occur in alkali-free laboratory preparations, but did exist if either or both $\mathrm{Na}_{2} \mathrm{O}$ and $\mathrm{K}_{2} \mathrm{O}$ were present. The mean refractive index of this weakly birefracting phase was found to be near 1.72. No crystals possessing optical properties similar to those of $\mathrm{K}_{2} \mathrm{O} \cdot \mathrm{Al}_{2} \mathrm{O}_{3}$ were observed.

Although the treatment in this paper has been concerned exclusively with equilibrium crystallization of the phases studied, it should not be lost sight of that clinker contains varying amounts of glass and that this glass may contain a part or all of the alkali components. The degree of crystallization of the alkali phases at any temperature can only be determined through further study of the course of crystallization now in progress.

\section{SUMMARY}

$A$ portion of the quaternary system $\mathrm{CaO}-\mathrm{Al}_{2} \mathrm{O}_{3}-\mathrm{Fe}_{2} \mathrm{O}_{3}-\mathrm{K}_{2} \mathrm{O}$ has been investigated. The quenching method of study was employed for the determination of temperature relations. The results of thermal and optical studies are presented. 
No additional compounds were observed in the regions studied. The maximum index of refraction of $\mathrm{K}_{2} \mathrm{O} \cdot \mathrm{Al}_{2} \mathrm{O}_{3}$ in the presence of the iron compounds is 1.625 .

The compounds $4 \mathrm{CaO} \cdot \mathrm{Al}_{2} \mathrm{O}_{3} \cdot \mathrm{Fe}_{2} \mathrm{O}_{3}$ and $\mathrm{K}_{2} \mathrm{O} \cdot \mathrm{Al}_{2} \mathrm{O}_{3}$ form a binary system with one eutectic.

For a given ratio of $4 \mathrm{CaO} \cdot \mathrm{Al}_{2} \mathrm{O}_{3} \cdot \mathrm{Fe}_{2} \mathrm{O}_{3}$ to $2 \mathrm{CaO} \cdot \mathrm{Fe}_{2} \mathrm{O}_{3}$, the solid solution of these two compounds and $\mathrm{K}_{2} \mathrm{O} \cdot \mathrm{Al}_{2} \mathrm{O}_{3}$ form a pseudobinary system with a definite lowest-melting composition.

Detailed thermal data are given.

Temperature-concentration diagrams for the various series were constructed.

The author gratefully acknowledges the assistance given by L. T. Brownmiller, formerly of this staff, who began this study and advised in outlining the procedure for its continuance.

\section{REFERENCES}

[1] L. T. Brownmiller and R. H. Bogue, BS J. Research 5, 813 (1930) RP233; Am. J. Sci. 20, 241 (1930).

[2] F. M. Lea and T. W. Parker, Bldg. Research Tech. Pap. 16 (1935).

[3] L. A. Dahl, Rock Products 35, No. 12, 31 (1932).

[4] H. F. McMurdie and H. Insley, J. Research NBS 16, 467 (1936) RP884.

[5] L. T. Brownmiller and R. H. Bogue, BS J. Research 8, 289 (1932) RP414; Am. J. Sci. 23, 501 (1932).

[6] L. T. Brownmiller, Am. J. Sci. 29, 260 (1935).

[7] Adams, J. Opt. Soc. Am. 9, 599 (1924).

[8] W. C. Hansen, L. T. Brownmiller, and R. H. Bogue, J. Am. Chem. Soc. 50, 396 (1928).

[9] W. C. Taylor, Unpublished data.

[10] H. Insley and H. F. McMurdie, J. Research NBS 20, 173 (1938) RP1074.

Washington, March 18, 1938. 